\title{
Mechanistic studies on the ring-opening polymerisation of $D$, L-lactide with zinc guanidine complexes
}

\author{
S Herres-Pawlis ${ }^{\text {* }}$, J Börner², Vieira I dos Santos², U Flörke ${ }^{2}$ \\ From 5th German Conference on Cheminformatics: 23. CIC-Workshop \\ Goslar, Germany. 8-10 November 2009
}

The increasing shortage of resources has enforced the search for production techniques for biodegradable polymers made of renewable raw materials. An example is polylactide (PLA), an aliphatic polyester, which can be obtained by the metal-catalysed ring-opening polymerisation (ROP) of lactide (Fig. 1). The monomer for PLA production is available from corn or sugar beets by a bacterial fermentation process in few steps [1] The PLA can be either recycled or composted after use, making the use $\mathrm{CO}_{2}$-emission-neutral. Most large-scale processes are based on the use of tin compounds as initiators [2]. However, for use in food packaging or similar applications, heavy metals are undesirable [3].

In order to substitute heavy-metal-based catalyst systems, especially zinc guanidine complexes are suited for the polymerisation due to their polymerisation activity and non-toxicity [4]. The investigations on the catalytic potential in the bulk polymerisation of lactide have shown that these compounds are able to act as initiators for lactide polymerisation with only few exceptions. Polylactides with molecular weights $\left(M_{W}\right)$ between 20.000 and $170.000 \mathrm{~g} / \mathrm{mol}$ could be obtained.

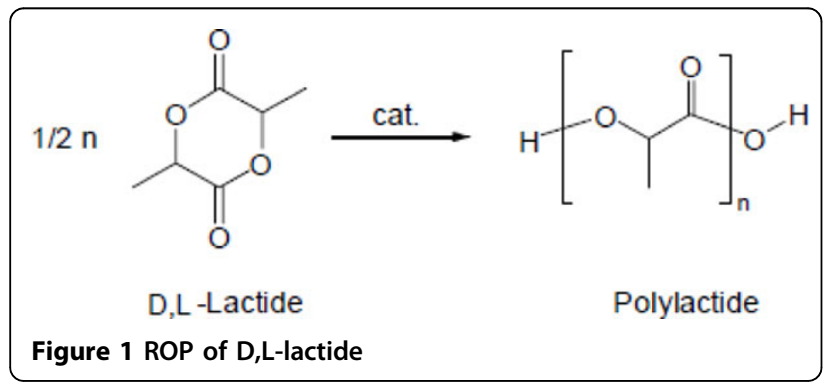

'TU Dortmund, Fakultät Chemie, 44221 Dortmund, Germany

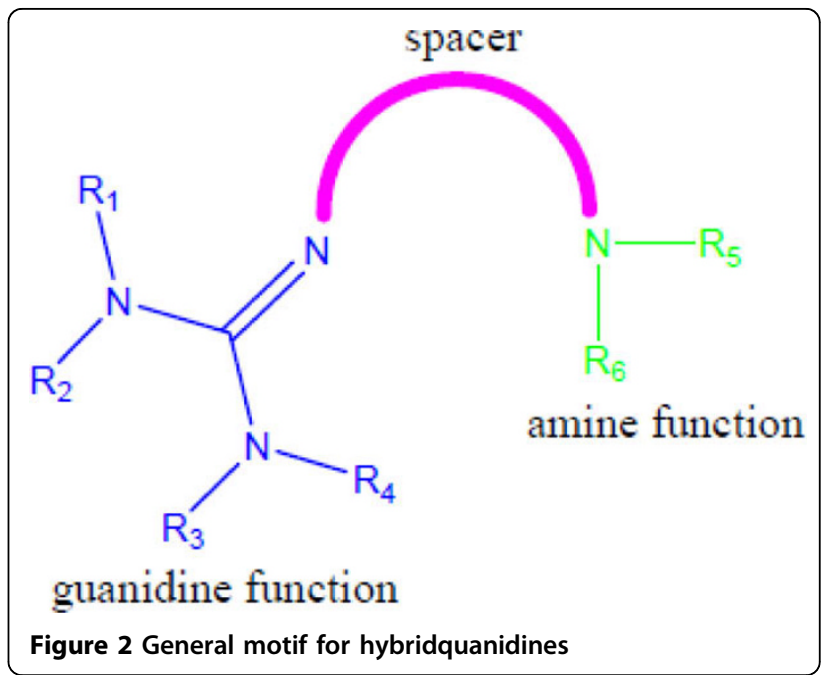

As the polymerisation activity depends strongly on the ligand structure (spacer, guanidine and amine unit), DFT studies on the complex properties have been performed [5]. A correlation between calculated partial charges on the zinc and the guanidine $\mathrm{N}$ atoms and the catalytic activity has been found. The guanidine is supposed to open nucleophilically the lactide ring and supersede the presence of alkoxides which is traditionally required. This crucial step in the ROP has been analysed by DFT and a mecha-nism will be presented. The deeper understanding of the catalytic transition state will enable a more efficient access to catalyst design. Figure 2.

Author details

${ }^{1}$ TU Dortmund, Fakultät Chemie, 44221 Dortmund, Germany. ${ }^{2}$ University of Paderborn, Paderborn, Germany. 


\section{References}

1. Bigg DM: Adv Polym Tech 2005, 24:69.

2. Kricheldorf HR, Meier-Haak J: Macromol Chem 1993, 194:715.

3. Kricheldorf HR: Chemosphere 2001, 43:49.

4. Börner J, Herres-Pawlis S, Flörke U, Huber K: Eur J Inorg Chem 2007, 5645.

5. Börner J, Flörke U, Huber K, Döring A, Kuckling D, Herres-Pawlis S: Chem Eur J 2009, 15:2362-.

\section{Publish with ChemistryCentral and every scientist can read your work free of charge}

"Open access provides opportunities to our colleagues in other parts of the globe, by allowing anyone to view the content free of charge."

$$
\text { W. Jeffery Hurst, The Hershey Company. }
$$

- available free of charge to the entire scientific community

- peer reviewed and published immediately upon acceptance

- cited in PubMed and archived on PubMed Central

- yours - you keep the copyright

Submit your manuscript here:

http://www.chemistrycentral.com/manuscript/<smiles></smiles>
Chemistry Central 